\title{
Investment in Ghana: An overview of FDI components and the impact on employment creation in the Ghanaian economy
}

\author{
Evans Yeboah * (D), Lucy Anning **(D) \\ * Nanjing University of Science and Technology, \\ 200 Xiaolingwei Street, 210094, Nanjing, Jiangsu Province, China \\ ** Accra Institute of Technology, \\ 34 Concam Cres, Accra, Ghana
}

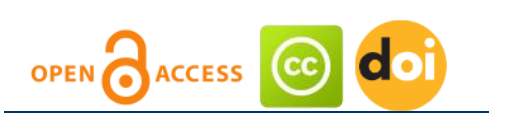

Article history:

Received: January 29, 2020

1st Revision: February 15, 2020

Accepted: April 13, 2020

JEL classification:
E22
F21
016

DOI:

10.14254/jems.2020.5-1.1

\begin{abstract}
As foreign direct investment provides a new way for many countries to improve their economies with Ghana not being an exemption. The source of FDI countries looks on to give Ghana a new way of advancement. This study provides a general overview on the inflow of foreign direct investment to Ghana. By considering FDI component values, local currency values, the overall number of projects registered and employment creation to investigate their significance in Ghana's economy. This study makes use of the descriptive statistical method that promote data analysis in a quantitative way. The results revealed that, FDI component contributes heavily to the total foreign direct investment values in Ghana. The outcome also shows that, of the whole number of registered projects, about $72.10 \%$ were whollyforeign owned but in the aspect of the aggregate cost of these projects, the value of joint ventures (between Ghanaians and their foreign counterparts) weigh higher than that of wholly-foreign owned businesses. The result further indicates that, on the account of employment creation, Ghanaians enjoyed about $85 \%$ of the total jobs to be created. It is suggested that the government of Ghana should encourage its citizen to contribute more to investment.
\end{abstract}

Keywords: FDI component, local currency component, total cost, employment, economy, Ghana. 


\section{Introduction}

Investment is essential for multinational companies, individual, governments and nations. In the situation of the nations, investment inflows and outflow are significant for its economic transformation and development. Recently, developing countries have defined economic growth as a key goal for improving their national economic structure, and it is understandable that global FDI inflows increased by 30\% to USD 1,979 trillion in 2007 (UNCTAD, 2008). The African continent continues to attract a meaningful share of foreign direct investment inflow across the globe as a result of institutional and structural reforms, and implementation of sound investment policies. This is because of the ongoing globalization and the redistribution or allocation of capital and wealth among nations with the idea of global competition (Joseph, 2015). However, the increasing passion towards FDI is not only because of globalization, but as a result of a continuous decline in foreign aids and development assistance from the developed economies and some fast growing nations such as China and India to developing and least developed countries. It is widely recognized that FDI will contribute to their economic development and incorporation into the world economy (Samuel, 2012). Foreign direct investment is now seen as a source of capital and an important instrument in the fight against poverty (Dr. John, 2005). Investment can be in the form of FDI and domestic within a country's economy. Foreign direct investment includes trans-border movement of capital. Foreign Direct Investment (FDI) is a cross-border investment made by a country A direct investor with the intention of creating a lasting interest in a country B incorporated undertaking (IMF, 1993).The position and value of FDI was at the center of a debate about which public policies are best suited to turn the former socialist world's emaciated state-owned economies into competitive market systems (Romer, 1986).

The flow of foreign direct investment (FDI) to Ghana started growing at a faster rate in 2006. Ghana is seen as a potential host country for investment as a result of its stable political environment and the abundance of natural resources. Recent enormous inflows of FDI into Ghana after oil discovery (Unctad, 2012). FDI flows to Ghana can be defined at best as erratic and at worst insignificant in order to generate and sustain economic growth (Prince \& Victor, 2014). Foreign capital pumped into the host economy may contribute to the construction of physical capital while the training of employees may contribute to the development of skills in the nation (Tee, Larbi, \& Johnson, 2017). FDI component share of the overall investment is vital to Ghana's economy. Foreign Direct Investment (FDI) is a major component of the capital flow to emerging developing economies (Baba, 2013). In Ghana's situation, investment values are made of FDI component and local currency component. However, there is always a partial transfer of the FDI component. In the aspect of capital accumulation turn to be a major challenge for most host countries due the FDI component money not frequently transferred in full. As for capital formation, Lipsey ${ }^{1}$ and other authors show that investors often fail to fully transfer capital when they take control of a foreign company; instead, they tend to finance a significant portion of their local mark et investment (Tee, Larbi, \& Johnson, 2017). As the FDI component is significant to capital accumulation in the host country, this paper is targeted on the analyses on the inflow of FDI in Ghana.

\section{Literature review}

Over the years, there have been many research papers done by numerous scholars on foreign direct investment in Ghana. Most of the papers were being focused on impact, determinants, linkage between FDI and gross domestic product (GDP) with different significance effect of FDI on Ghana's economy. However, majority of these research works done on FDI failed to provide an insight of the FDI component of the total estimated value of projects registered in Ghana. As a result of limited studies related to this study, this literature covers some of the papers published on FDI in Ghana.

A research investigating Ghana's FDI exposure to selected nations recorded foreign direct investment inflows between 2000 and 2014. Comparing quantitative data, the study showed that selected countries contributed more to Ghana's agriculture, manufacturing, construction / construction and service sectors in terms of investment volumes and projects relative to others to percentage of domestic employment in selected countries was higher than the percentage of domestic employment in other sectors of the economy due to incentives attached to priority economic sectors and job generation due to Ghana's investment laws, which require investors with

1 Lipsey (2020). Home and Host Country Effects of FDI. NBER Working Paper 9293. 
a specific minimum capital of three hundred thousand dollars use minimum of 10 Ghanaians for each foreign worker employed (Kwasi \& Yao, 2017).

The effect of China's foreign direct investment float on employment of Republic of Ghana of which the primary question of the take a glance at is the significance of Chinese investment on job creation in Ghana. This research became restrained to the employment activities Chinese investments have impacted in the economy of Ghana and was set to determine the quality of goods and offerings rendered to the various economic sectors of Ghana; the function of Chinese FDI in Ghanaian financial system and other monetary flows such as loans, improvement assistance between China and Republic of Ghana. The outcome suggests that approximately $80 \%$ or extra of investments from China has been by and large centered within the Manufacturing, Building \& Construction and General Trade sectors of the economic system of Republic of Ghana for the past five years (Which from 2006 to 2010) (Decai \& K, 2012).

A study which suggests notwithstanding the importance generated by FDI flows, the drift to developing international locations and the globe, in general, has witnessed chronic decline over the years and the implication for the drop method that opposition to attract FDI has increased as growing international locations hold to produce the enabling environment to attract foreign investors, Ghana, specially, has, throughout the last decade, pursued various kinds of monetary reforms and relaxation of trade regimes so as to come to be more aggressive in the international monetary market. Employing a regression analyses the outcome of the paper capture change openness, change rate, natural resources, and infrastructure as the drivers of FDI in Ghana (George, James, \& Peter, 2013).

A research base on reviewing papers posted on overseas direct investment (FDI) on Ghana to determine the factors that gravitate FDI into Ghana, the effects of FDI on Republic of Ghana and discover the gaps that exist for similarly research; the review discovered a booklet bias in the direction of inward FDI, commercial enterprise in journals outside Ghana and a preponderance of use of time collection data (Justice \& Gloria, 2012).

An examination, which addresses however Governments of Ghana has made tremendous effort over the past decade at attracting property Foreign Direct Investment (FDI) inflows to enhance its Gross Domestic Product (GDP) and other monetary indicators, that explores whether or not FDI inflows have had any full-size impact on GDP increase rate, the consequences suggest that FDI inflows have had an influence on GDP boom, it is however crucial to note that there are other important macroeconomic variables which need to be thought of (Francis, Mary, \& Jonatha, 2013).

When taking into account FDI in Ghana, there are components of FDI, which is the combination of foreign and local currencies. According to the Ghana Investment Promotion Centre, investment in Ghana is made up of FDI component values and the local currency values which sum up to the total estimated value of investment for a particular period of time. Conversely, in our situation we seek to provide detailed values of FDI component and the local currency component as most of FDI inflow to the Ghanaian economy comes in joint ventures (between Ghanaians and a foreign counterpart) and wholly owned enterprises by a foreign investor.

\section{FDI component explanation}

Foreign direct investment components can be about many, but this is going to focus on the two main components. According to the IMF suggestion in its balance of Payment Manual stated that an investor should hold at least 10\% control of their investment in other countries other than its parent nation. The $10 \%$ threshold is the criterion to determine whether (or not) an investor has have an impact on over the management of an enterprise, and, therefore, whether the idea for an instantaneous investment courting exists or not (OECD, 2008). It has been argued that in practice there are several elements which may decide the influence a right away investor has over the direct funding enterprise (OECD, 2008). The funding situation in Ghana allows $100 \%$ ownership by means of investors manipulate over their funding and recruitment of greater $70 \%$ of expatriates for corporations which requires special expertise.

The main monetary instrument additives of foreign direct funding (FDI) are equity and debt instruments.

Equity; this is the sum of the value of multinational companies' investments in share of an organization or enterprise in a foreign nation. An equity capital can be about 10 percent or above. On the account of foreign direct investment recorded by the Ghana Investment Promotion Centre mostly deals with equity Capital. However, the OECD explained equity as not unusual and favored stocks (special of non-participating preference stocks which ought to be included beneath debt), reserves, capital contributions and reinvestment of earnings (OECD, 2008) Conversely, all crossborder places and tractions in fairness between foreign direct investment (FDI)associated enterprises considered in overseas direct investment. Dividends, disbursed branch earnings, 
reinvested income and undistributed branch earnings are additives of FDI profits on equity (OECD, 2008).

Debt units; include marketable securities which includes bonds, debentures, commercial paper, promissory notes, non-participating choice shares and different tradable non-fairness securities as well as loans, deposits, trade credit score and other debts payable/ receivable(OECD, 2008). This includes all global positions and transactions related to these units, between businesses covered with the aid of a foreign direct funding relationship aside from between related monetary intermediaries are in considered in FDI. The interest returns on the above gadgets are protected in FDI income on debt (OECD, 2008).

\section{Sources of investment in Ghana}

Investment inflow are mostly from developed nations and some developing economies such as China and India. Ghana attracts most of its FDI registered projects from the Asian continent of which China is the top leading investing country followed by India. However, in most cases the Netherlands often tops in the aspect of the monetary value of these foreign direct investment projects. The United States and the United Kingdom contribution to investment in Ghana is at a decline level. Conversely, the European continent is the largest source of investment flow within the Ghanaian economy. Comparatively, the two Asian countries investment in terms of number of projects weigh higher than that of the European nations. The following nations are some of the top sources of FDI; China, India, Lebanon, United Kingdom, United States of America, Germany, Nigeria, Netherland, Italy and South Korea.

\section{Research methodology and data source}

The purpose of this study is to analyze FDI components in Ghana. Observing the trend of foreign direct investment flow from the source of foreign direct investment contribution to Ghana's economic growth. As the trend of foreign direct investment becomes very difficult to observe as a result of changes in data on a yearly basis. With respect to this study there is a meaningful data available for the objective of this study to be carried out. In this case, to execute the target outlined in this paper, a statistical descriptive method which supports the analysis of the impact of foreign direct investment (FDI) in a quantitative way.

According to the literature review of this paper, it can be observed that the majority of studies have not been conducted in this mode, therefore limited amount of conceptual framework for the concept of hypothesis testing. The main set of data will focus on the overall total values FDI component and local currency component, number of registered projects, total cost of FDI registered projects and the number of employments to be created. The study makes use of secondary sources of data from the Ghana Investment Promotion Centre (GIPC) investment reports from 2013 to 2018. The Ghana Investment Promotion Centre is the sole institution established by the government of Ghana under the Act, 2013 (Act 865) to encourage, regulate and promote investment activities in the country.

\section{Results}

\section{Total FDI values}

The total estimated value (amount) is classified into FDI component and local currency component as a result of funds pulled together by a foreign investor and their Ghanaian counterpart in the situation of a joint venture investment. However, the summation of the total FDI component and the local currency component equal to the total FDI amount recorded. Breakdown of the total value generated from 2013 to 2018 is based on the sectoral distribution among the sectors categorized by the Ghana Investment Promotion Centre, which includes areas such as mining and oil and gas services, ICT and financial services. Between 2013 and 2018, the Ghana Investment Promotion Centre recorded an estimated total value of US\$ 20,227.652 million of foreign direct investment inflow to Ghana's economy. However, the total estimated value of FDI was categorized into FDI component and local currency component on a yearly basis. The table 1 below shows a breakdown FDI value from 2013 to 2018. 


\begin{tabular}{ccccc}
\hline $\begin{array}{c}\text { Table 1: Breakdown of FDI values to Ghana from } \mathbf{2 0 1 3} \text { to } \mathbf{2 0 1 8} \\
\text { Year }\end{array}$ & $\begin{array}{c}\text { FDI } \\
\text { component(US\$M) }\end{array}$ & $\begin{array}{c}\text { Local Currency } \\
\text { Component(US\$) }\end{array}$ & $\begin{array}{c}\text { Total FDI value } \\
\text { (US\$) }\end{array}$ & \% Share \\
\hline 2013 & $3,945.65$ & 315.61 & $4,261.26$ & 21.10 \\
2014 & $3,387.96$ & 181.61 & $3,569.57$ & 17.60 \\
2015 & $2,329.3$ & 351.31 & $2,680.61$ & 13.30 \\
2016 & $2,236.97$ & 192.01 & $2,428.98$ & 12.00 \\
2017 & $3,614.07$ & 131.53 & $3,745.6$ & 18.50 \\
2018 & $3,325.05$ & 216.577 & $3,541.632$ & 17.50 \\
Total & $\mathbf{1 8 , 8 3 9 . 0}$ & $\mathbf{1 , 3 8 8 . 6 4 7}$ & $\mathbf{2 0 , 2 2 7 . 6 5 2}$ & $\mathbf{1 0 0 . 0 0}$ \\
\hline
\end{tabular}

Source: Author's calculations based on the data from the Ghana Investment Promotion Centre

Figure 1: Total FDI value verse FDI component and Local currency component

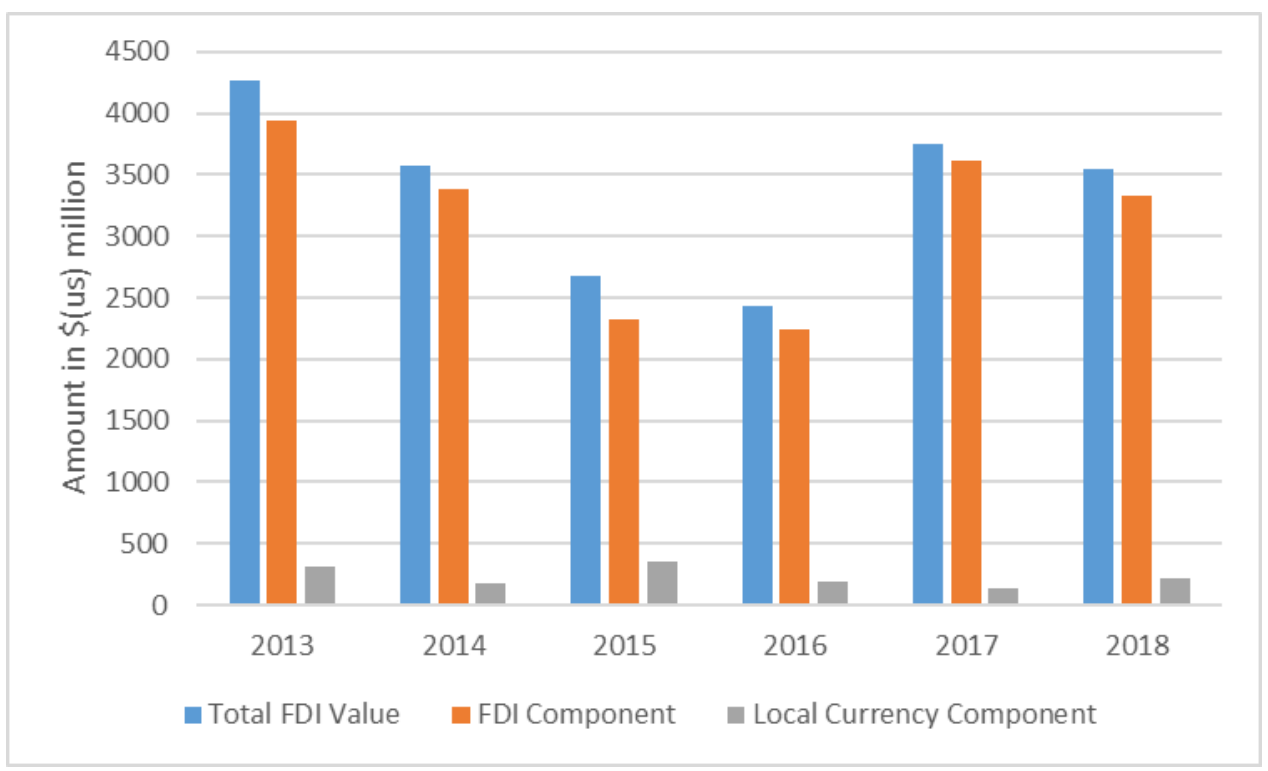

Source: Author's calculations based on the data from the Ghana Investment Promotion Centre

From the table 1 and figure 1 above clearly shows that foreign direct investment (FDI) component attained a maximum value (amount) in 2013 and relatively a continual decline between 2014 and 2016. However, the FDI component increased in 2017 and a decreased in 2018. Between 2013 and 2018, FDI component attained a percentage share of 93.13 whilst the local currency component obtained $6.87 \%$ of the total amount of foreign direct investment inflow. On the other hand, local currency component recorded the highest value in 2015 and a decrease from 2016 to 2018. The total FDI inflow value achieved a greater percentage share in 2013 whereas there was a decline in values from 2014 to 2016 and an increase in 2017.

\section{Total number of FDI registered projects}

The Ghana Investment Promotion Centre recorded a total number of 1,312 foreign direct investment projects between 2013 and 2018. The FDI registered projects are classified into whollyforeign owned (100\% ownership by a foreign investor) and a joint venture (between Ghanaians and their foreign counterparts). The sum of the overall FDI registered projects recorded within a particular investment fiscal year is the addition of wholly-foreign owned enterprises and joint ventures between Ghanaians and foreign partners. The table 2 beneath shows a breakdown of the total number of FDI. 


\begin{tabular}{|c|c|c|c|c|}
\hline Year & $\begin{array}{c}\text { Wholly-Foreign } \\
\text { Owned }\end{array}$ & Joint Venture & Total & $\%$ Share \\
\hline 2013 & 311 & 107 & 418 & 31.86 \\
\hline 2014 & 135 & 49 & 184 & 14.02 \\
\hline 2015 & 110 & 60 & 170 & 12.96 \\
\hline 2016 & 129 & 51 & 180 & 13.72 \\
\hline 2018 & 117 & 51 & 168 & 12.80 \\
\hline Total & 946 & 366 & 1,312 & 100.0 \\
\hline
\end{tabular}

Source: Author's calculations based on the data from the Ghana Investment Promotion Centre

Figure 2: Total Number of FDI projects verse wholly-foreign owned and joint venture

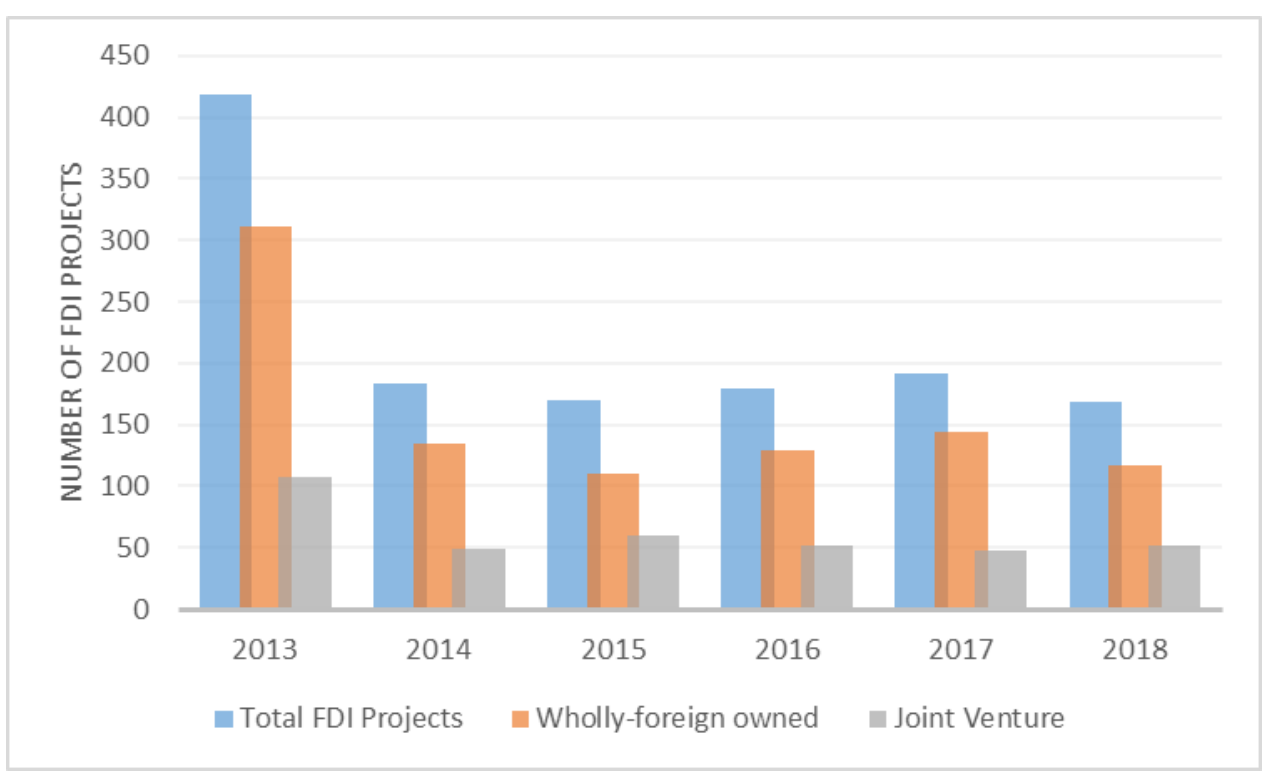

Source: Author's calculations based on the data from the Ghana Investment Promotion Centre

From the table 2 and figure 2 above shows that, the highest number of registered foreign direct investment projects occurred in 2013. There is a clear indication that, there is a continual decline in the yearly total registered projects from 2014. However, wholly-foreign owned and joint venture registered projects attained their highest number in 2013. Conversely, a reduction in the total FDI projects has a direct relationship on both wholly- foreign owned and joint venture. The percentage share of the total FDI projects for wholly-foreign owned and joint venture are 72.10 and 27.90 respectively.

\section{Total cost of FDI registered projects}

The total cost of FDI registered projects is accumulated through the addition of the values of FDI component and local currency component which is as a result of the registered wholly-foreign owned businesses and joint ventures. Each registered project comes with a monetary value which classified as the estimated cost. The cost of FDI projects are found in various sectors within the Ghanaian economy. However, between 2013 and 2018 the total cost of registered projects for wholly-foreign owned and joint ventures accounted for $\$$ US $20,231.917$. However, there was a continual decline in the total cost of registered FDI projects from 2014 to 2016. The total cost of project attained its biggest amount in 2013. Conversely, a decrease in the total number of registered projects has an adverse effect on the total cost. The table 3 and figure 3 shows a breakdown of the total cost of FDI projects in Ghana. 


\begin{tabular}{ccccc}
\multicolumn{4}{c}{ Table 3: Breakdown of total cost of FDI projects in Ghana from 2014 to 2018 } \\
\hline Year & $\begin{array}{c}\text { Wholly-Foreign } \\
\text { Owned cost \$USM }\end{array}$ & $\begin{array}{c}\text { Joint venture cost } \\
\text { \$USM }\end{array}$ & $\begin{array}{c}\text { Total cost of } \\
\text { projects \$USM }\end{array}$ \\
\hline 2013 & $1,875.15$ & $2,386.13$ & $4,261.28$ & \%Share \\
2014 & $1,541.46$ & $2,028.107$ & $3,569.567$ & 21.06 \\
2015 & $1,907.02$ & 773.62 & $2,680.64$ & 17.64 \\
2016 & 650.94 & $1,783.5$ & $2,434.44$ & 13.26 \\
2017 & 965.25 & $2,780.08$ & $3,745.33$ & 12.03 \\
2018 & $2,887.7$ & 652.96 & $3,540.66$ & 18.51 \\
Total & $\mathbf{9 , 8 2 7 . 5 2}$ & $\mathbf{1 0 , 4 0 4 . 3 9 7}$ & $\mathbf{2 0 , 3 2 1 . 9 1 7}$ & $\mathbf{1 0 0 . 0}$ \\
\hline
\end{tabular}

Source: Author's calculations based on the data from the Ghana Investment Promotion Centre

Figure 3: Total cost of FDI projects verse wholly-foreign owned cost and joint venture cost

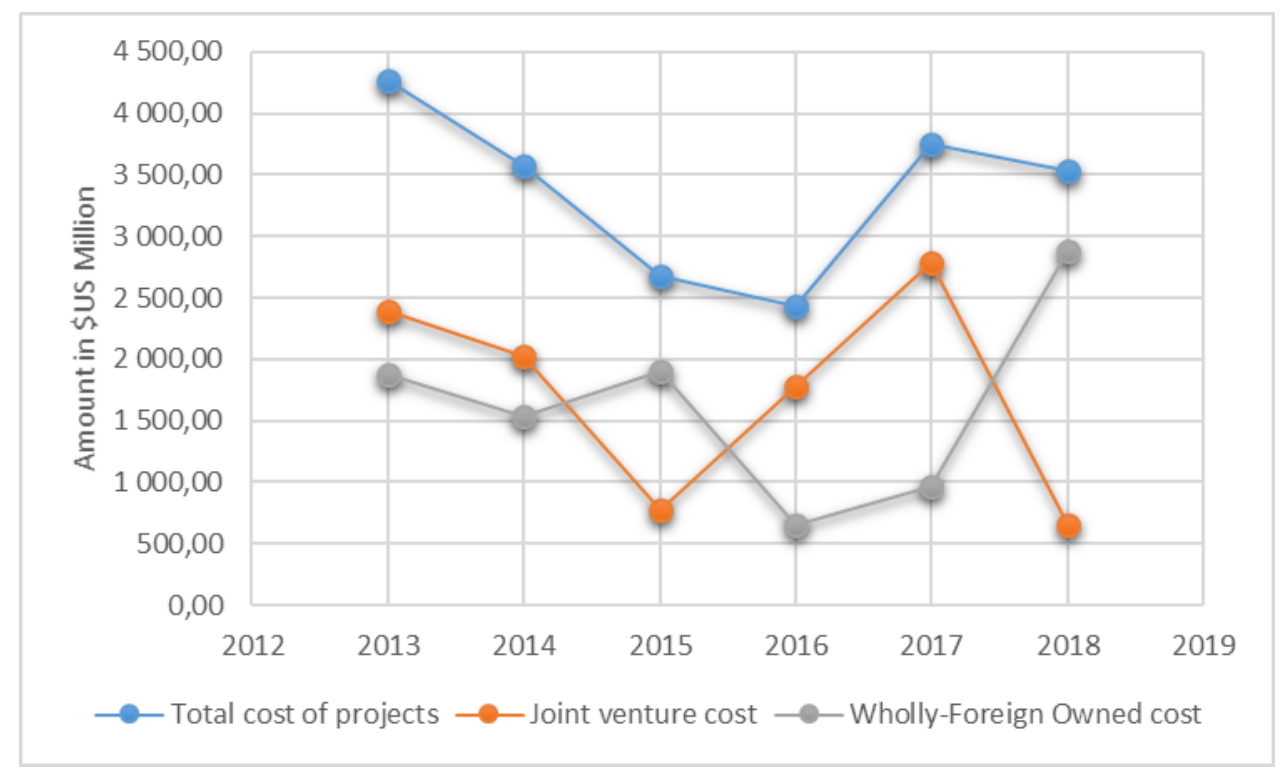

Source: Author's calculations based on the data from the Ghana Investment Promotion Centre

From table 3 and figure 3 above indicates that, the total cost of registered foreign direct investment project highest amount was in 2014. Comparatively wholly-foreign owned total number of registered projects values weigh lower than joint ventures. The percentage share of the total cost of joint venture and wholly-foreign owned are $51.43 \%$ and $48.57 \%$ respectively.

\section{Sectoral distribution of FDI projects and cost}

Under the classification of sector under the Ghanaian economy where investment goes are categorized into eight excluding the oil sector. The sector includes Agricultural, Building and Construction, Export trade, General trading, Liaison, Manufacturing, Service and Tourism. The sectorial performance from the various sector turns to attract major foreign and local investors. Base on the yearly reports from the Ghana Investment Promotion Centre indicates that majority of FDI projects are found in the Manufacturing and service sectors. However, from 1994 to 2013, there was a total number of 4,714 registered projects recorded by the Ghana Investment Promotion Center of which $22.14 \%$ of these projects were absorbed by the manufacturing sector, $29.29 \%$ in the service sector, $16.35 \%$ in the general trading, $8.67 \%$ in building and construction, $8.54 \%$ to the tourism sector, $5.17 \%$ in liaison, $5.13 \%$ and $4.66 \%$ in the agriculture and export trade respectively (Kusi, 2013). The table blow shows the sectorial distribution of registered FDI projects and their respective cost. 


\begin{tabular}{lcc} 
Table 4: Sectorial distribution of registered FDI projects and their cost from 2013 to 2017 \\
\hline Sectors & Number of Projects & Estimated cost in \$USM \\
\hline Agricultural & 29 & 210.46 \\
Building \& Const & 120 & $2,378.92$ \\
Export Trade & 35 & 59.12 \\
General Trading & 194 & 638.04 \\
Liaison & 134 & $1,468.67$ \\
Manufacturing & 252 & $5,223.44$ \\
Service & 346 & $5,530.02$ \\
Tourism & 31 & 696.71 \\
\hline
\end{tabular}

Source: Author's calculations based on the quarterly reports from GIPC

However, according to the Ghana Investment Promotion Centre 168 projects were recorded in 2018 and of the 168 projects recorded from January to December 2018, 117 were wholly foreign owned with total investment value of US\$ 2.89 billion. The remaining 51 were Joint Ventures between Ghanaians and their foreign counterparts which amounted to US\$ 652.02 million. The breakdowns are provided in the tables below respectively

\begin{tabular}{lcc}
\hline \multicolumn{1}{l}{ Table 5: Wholly Foreign Owned Projects (Jan-Dec. 2018) } & \\
\hline \multicolumn{1}{l}{ Sectors } & Number of Projects & Estimated cost in \$USM \\
\hline Agricultural & 2 & 6.25 \\
Building \& Const. & 11 & $1,091.28$ \\
Export Trade & 6 & 2.23 \\
General Trading & 25 & 109.98 \\
Liaison & 17 & 153.55 \\
Manufacturing & 39 & 549.64 \\
Service & 37 & 974.69 \\
\hline
\end{tabular}

Source: The Ghana Investment Promotion Centre $4^{\text {th }}$ quarter report 2018

\begin{tabular}{lcc}
\hline Table 6: Joint Venture Projects (Jan-Dec. 2018) & \\
Sectors & Number of Projects & Estimated cost in \$USM \\
\hline Agriculture & 4 & 2.66 \\
Building \& Const. & 4 & 46.22 \\
General Trading & 7 & 27.63 \\
Manufacturing & 11 & 133.58 \\
Service & 25 & 442.87 \\
\hline
\end{tabular}

Source: The Ghana Investment Promotion Centre $4^{\text {th }}$ quarter report 2018

\section{Impact of FDI on employment}

This section of the paper will target on the expected number of employment to be generated from the registered FDI projects, which is made up of the statistics of Ghanaians and expatriates to benefit. These employments are found in the various sectors of the Ghanaian economy as a result of the distribution of the registered projects in the sectors. However, the total number of expected jobs to be created for Ghanaian and Non-Ghanaians between 2013 and 2018 was 159,764. The table beneath shows breakdown of the total employment to be created.

\begin{tabular}{lllll}
\multicolumn{6}{l}{ Table 7: Breakdown of FDI total employment to be created from $\mathbf{2 0 1 3}$ to $\mathbf{2 0 1 8}$} \\
\hline Year & Ghanaians & Expatriates & Total & \%share \\
\hline 2013 & 76,109 & 13,085 & 89,194 & 55.82 \\
2014 & 11,670 & 1,452 & 13,122 & 8.21 \\
2015 & 13,534 & 1,414 & 14,948 & 9.38 \\
2016 & 10,156 & 1,263 & 11,419 & 7.14 \\
2017 & 11,821 & 1,340 & 13,161 & 8.24 \\
2018 & & & & 11.21 \\
Total & 11,843 & 6,077 & 17,920 & $\mathbf{1 0 0 . 0}$ \\
\hline
\end{tabular}

Source: Author's calculations based on the data from the Ghana Investment Promotion Centre 
Figure 4: The total number of employment verse employment for Ghanaians and Expatriates

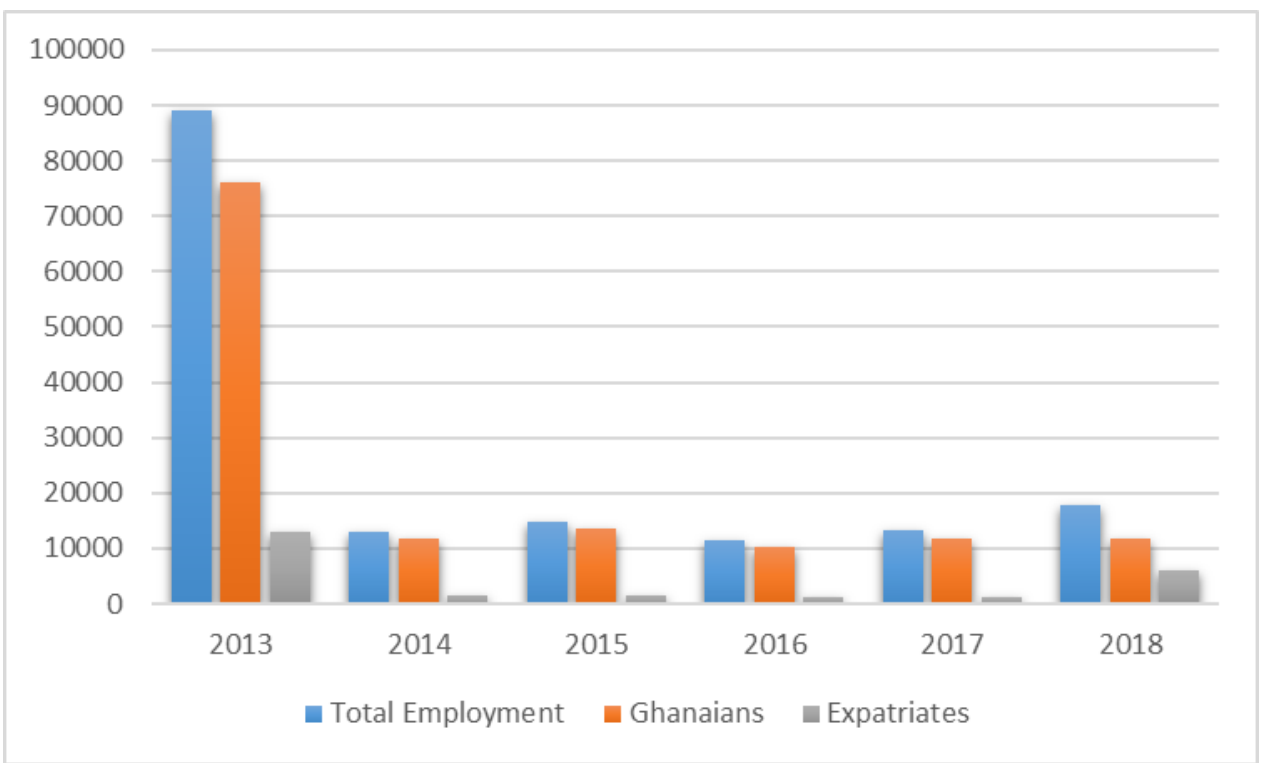

Source: Author's calculations based on the data from the Ghana Investment Promotion Centre

From table 7 and figure 4 above clearly shows that the total number of employments to be generated for Ghanaians and expatriates recorded its highest in 2013 and this is due to a huge number of foreign direct investment registered projects in the same year. Of the total number of employments generated between 2013 and 2018, 84.58\% of jobs were at full capacity for Ghanaians and $15.42 \%$ to expatriates.

\section{Summary of findings and conclusion}

From the outcomes of this study, about $93.13 \%$ of foreign direct investment total value between 2013 and 2018 came from FDI component and 6.87\% to the local Currency. From 2013 to 2018, about $72.10 \%$ of investment from the source of FDI in Ghana were wholly-foreign owned enterprises and $27.90 \%$ to joint ventures. However, about $51.43 \%$ of the total cost of FDI registered projects was for joint venture and $48.57 \%$ to wholly-foreign owned businesses. On the other hand, between 2013 and 2018, about 84.58\% of the total employment projection creations were for Ghanaians. The government of Ghana should encourage its citizen to contribute more to investment. A more effective and efficient contribution from the local currency component in spite of foreign direct investment appraisals will not allow domestic investors' operations improved. The geographical target should broaden reach other component because this survey may not represent all the various components of FDI in Ghana. This can bring out more shortfalls of all the FDI components and values under review and aid the researcher correct and adopt tactics and strategies to enhance the Ghanaian economy. This study may not be applicable in other nations since the main target was limited to Ghana.

\section{Acknowledgements}

We thank Mr. Yeboah Michael, Ronnie Payne, Antwi Agyeiwaah Vivian, Animah Florence, Yu Jing an Associate Professor in the School of Economics and Management at Nanjing University of Science and Technology, Frimpong Boateng Evans a PHD student at the International Educa-tion Collage of Nanjing Agriculture University and Angela Mangie Ama Tay of Bohai Univer-sity for every support execute in making this work a reality. Thank You Very Much. 


\section{Appendix A. Supplementary material}

Supplementary data associated with this article can be found, in the online version, at https://doi.org/10.14254/jems.2020.5-1.1

\section{Funding}

The authors received no direct funding for this research.

\section{Citation information}

Yeboah, E., \& Anning, L. (2020). Investment in Ghana: An overview of FDI components and the impact on employment creation in the Ghanaian economy. Economics, Management and Sustainability, 5(1), 6-16. doi:10.14254/jems.2020.5-1.1.

\section{References}

Baba, I. (2013). Foreign direct investment inflows and economic growth in Ghana. International Journal of Economic Practices and Theories, 3(2).

Decai, T., \& K, B. (2012). China - Africa foreign trade policies: the impact of China's foreign direct investment (FDI) flow on employment of Ghana. 2012 International Conference on Future Energy, Environment, and Materials. 16, pp. 553-557. Energy Procedia.

Dr. John, A. (2005). What has been the impact of foreign direct investment in Ghana?. IEA Policy Analysis. The Institute of Economic Affairs, 1(9).

Francis, G., Mary, O., \& Jonatha, K. E. (2013). Foreign direct investment and gross domestic product in Ghana. International Journal of Academic Research in Accounting, Finance and Management Sciences, 3(3), 256-265.

George, O.-A., James, A., \& Peter, K. (2013). Foreign direct investment: A journey to economic growth in Ghana - Empirical Evidence. International Business \& Economics Research Journal, $12(5)$.

IMF. (1993). Balance of Payments Manual, 5th edition. Washington D.C: International Monetary Fund.

Joseph, Y. A. (2015). Chinese Investment in Ghana. Argumenta Oeconomica Cracoviensia, (13), 6181.

Justice, G., \& Gloria, C. (2012). Determinants and effects of foreign direct investment in Ghana Review of literature. Developing Country Studies, 2(11).

Kusi, G. (2013). Regulatory Framework for Investing in Ghana. Ghana Investment Promotion Centre.

Kwasi, B.-G., \& Yao, L. (2017). FDI trends in Ghana: The role of China, US, India and South Africa. Eurasian Journal of Economics and Finance, 5(2), 1-16.

OECD. (2008). OECD Benchmark definition of foreign direct investment. In OECD, OECD Benchmark Definition of Foreign Direct Investment (4th ed., pp. 62-64). Paris: OECD.

Prince, A., \& Victor, O. (2014). Foreign Direct Investment (FDI) Inflows into Ghana: Should the Focus Be on Infrastructure or Natural Resources? Short- Run and Long -Run Analyses. International Journal of Financial Research, 5(1).

Romer, P. (1986). Increasing returns and long run growth. Journal of Political Economy, 94(5), 1002-1037.

Samuel, K. F. (2012). Research on Relationship between China and Ghana: Trade and Foreign Direct Investment. Journal of Economics and Sustainable Development, 3(7).

Tee, E., Larbi, F., \& Johnson, R. (2017). The Effect of foreign direct investment (FDI) on the Ghanaian economic growth. Journal of Business and Economic Development, 2(5), 240-246. 
Unctad. (2012). World investment report: Towards a new generation of investment policies. New York and Geneva: United Nations Conference on Trade and Development.

UNCTAD. (2008). World Investment Report: Transnational Corporations and the Infrastructure Challenge. New York: United Nations Conference on Trade and Development.

(c) 2016-2020, Economics, Management and Sustainability. All rights reserved.

This open access article is distributed under a Creative Commons Attribution (CC-BY) 4.0 license.

You are free to:

Share - copy and redistribute the material in any medium or format Adapt - remix, transform, and build upon the material for any purpose, even commercially.

The licensor cannot revoke these freedoms as long as you follow the license terms.

Under the following terms:

Attribution - You must give appropriate credit, provide a link to the license, and indicate if changes were made.

You may do so in any reasonable manner, but not in any way that suggests the licensor endorses you or your use.

No additional restrictions

You may not apply legal terms or technological measures that legally restrict others from doing anything the license permits.

Economics, Management and Sustainability (ISSN: 2520-6303) is published by Scientific Publishing House "CSR", Poland, EU and Scientific Publishing House "SciView", Poland

Publishing with JEMS ensures:

- Immediate, universal access to your article on publication

- High visibility and discoverability via the JEMS website

- Rapid publication

- Guaranteed legacy preservation of your article

- Discounts and waivers for authors in developing regions

Submit your manuscript to a JEMS at http://jems.sciview.net or submit.jems@sciview.net

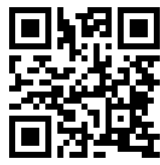

